\title{
Management of Fishery Resources: A Starting Point Towards Cooperation in the East China Sea
}

\author{
Kuan-Hsiung Wang
}

\section{I \\ Introduction}

The disputes in the East China Sea could be categorized into two parts: one is on the sovereignty of those island features, and the other is the maritime zones claimed by related Parties in the region. It is understandable that the best way to solve the disputes might be delimiting boundaries so that the areas of sovereignty and jurisdiction could be decided. However, such situation is not always possible. It is mainly because negotiation and adoption of a maritime boundary between the related Parties always focused on political considerations and there are no well-established as well as well-recognized regulations for making boundaries. It is recognized that "equitable solution" is one of the most important principles in boundary making. However, there are no definite elements which have been decided in jurisprudence. There have been cases which recognize geographical and geological factors, coastal length, traditional fishing activities, relative impact on the livelihood and economic dependency as considerations in setting maritime boundaries.

Under such circumstances, joint development/joint cooperation then could be treated as a way to solve the disputes. This is not only an expectation made by the related Parties, but could also be found in the 1982 United Nations Convention on the Law of the Sea (UNCLOS). Articles 74(3) and 83(3) of UNCLOS, ${ }^{1}$ both provide "provisional arrangements" in situations before the boundary lines are agreed upon. The term "provisional arrangement" could be interpreted to refer to "joint cooperation" which is a popular term quoted and cited by the leaders of the Parties in the region. However, no practical exercises have been realized. Lack of political will is a possible reason.

It is not difficult to locate opportunities for joint cooperation in the East China Sea region. Joint military exercises, joint development of hydrocarbon

1 UNCLOS Article 74(3) provides "Pending agreement as provided for in paragraph 1, the States concerned, in a spirit of understanding and cooperation, shall make every effort to enter into provisional arrangements of a practical nature and, during this transitional period, not to jeopardize or hamper the reaching of the final agreement. Such arrangements shall be without prejudice to the final delimitation".

(C) KUAN-HSIUNG WANG, 2019 | DOI:10.1163/9789004379633_005

This is an open access article distributed under the terms of the prevailing CC-BY-NC License at the time of publication. 
resources, marine scientific research, marine environmental protection and fisheries cooperation are options to this end. To date, however, disputes surrounding possible hydrocarbon resources in the area and actions in favor of conservation and management of fishery resources have been delayed. Nevertheless, conservation and management of fishery resources could be the starting point for cooperation in this region and could have a "spillover effect" into other areas of cooperation. Moreover, there might be possibilities that the disputes could be solved through peaceful means.

In this respect, cooperating to manage and conserve fisheries resources is especially significant because fish are migratory, and even some of them are highly migratory. Moreover, overfishing is a serious and pressing problem in the region. In this regard, a maritime boundary cannot entirely protect a State's fishery resources from encroachment, because fishery resources migrate beyond the State's jurisdiction, and overfishing beyond its borders could also have great impact on the fish stocks within its territorial boundaries.

Therefore, a proper management mechanism, subject to natural conditions, is necessary for the coastal States to keep stocks at sustainable levels. This is especially important for the littoral States around the East China Sea. Because this region is a semi-enclosed sea in its geographical features, ${ }^{2}$ any change in the fishery policy-making could have far-reaching effects on the continuation of the fishery resources in this area.

\section{Issues in the East China Sea}

The development of globalization has already become an important phenomenon in the modern international society. Such phenomenon was demonstrated in the economy elements of production flowing with an unprecedented speed and scale in the global scope. Although the process of globalization has been witnessed for several decades, it is still under a drastic debate if globalization would cause the collapse of national boundaries. Furthermore, will States be collapsed in the future due to their functions have been restricted?

For discussions or debates on "globalization", most of them are on international financial transaction, technology flows, transnational cooperation, capital flows, cross border movements of people, and so forth. In other words,

2 UNCLOS Article 122 provides that "[E]nclosed or semi-enclosed sea" means a gulf, basin or sea surrounded by two or more States and connected to another sea or the ocean by a narrow outlet or consisting entirely or primarily of the territorial seas and exclusive economic zones of two or more coastal States. 
States, as the members of the international community, are getting closer and sharing common interests. Therefore, more functional fields, and even disputes, are emerging.

It is a trend that national sovereignty had been challenged by the developments mentioned above. Not only such phenomenon appears in daily economic life, but also appears in the development of the international legal system, especially in the fields of high seas fisheries and international environmental protection.

For purposes of statistics concerning fish catches, a list of major fishing areas is maintained by the FAO. ${ }^{3}$ The East China Sea region is within Area 61, which is under the title of Northwest Pacific. In terms of global production of marine capture fisheries, global capture fisheries production in 2008 was about 90 million tonnes, with an estimated first-sale value of US $\$ 93.9$ billion, comprising about 80 million tonnes from marine waters. In 2008, the Northwest Pacific had the highest production of 20.1 million tonnes (25 per cent of the global marine catch), followed by the Southeast Pacific, with a total catch of 11.8 million tonnes (15 per cent), the Western Central Pacific with 11.1 million tonnes (14 per cent) and the Northeast Atlantic, with 8.5 million tonnes (11 per cent). ${ }^{4}$ More specifically, the fish capture production of 2010 in Area 61 by China, Korea, Japan and Taiwan is 12.7 million tonnes, 1.2 million tonnes, 3.6 million tonnes, and 0.4 million tonnes. ${ }^{5}$ This demonstrates the fact that China's fish capture production occupies most of the volume comparing with other States in the Northwest Pacific area.

The East China Sea is a marginal sea in the west Pacific Ocean as well as the west part of the aforementioned FAO fishing Area 61. It is an area of about 700,00o square kilometers to the east of China, north of Taiwan, west of Japan's Ryuku islands, and south of Korea. The eight Daioyu/Senkaku (Chinese name/ Japanese name) Islands are to the northeast of Taiwan, the largest island, with the area of 4.32 square kilometers, is two miles long and less than a mile wide. Though incapable of sustaining life, the islands are important for strategic and political reasons, as claims of ownership are used to bolster claims to the surrounding sea and its resources. ${ }^{6}$ That causes the conflicts for the countries surrounding the maritime area, which makes it one of the flashpoints in the east Asia.

3 Available at http://www.fao.org/fishery/area/search/en.

4 Fao, World Review of Fisheries and Aquaculture 35 (2010).

5 FAO, FAO YEARBOOK 2010 (2012).

6 Energy Information Administration, Country Analysis Briefs: East China Sea, available at http://www.eia.gov/EMEU/cabs/East_China_Sea/pdf. 
Although it is reported that the oil reserve is abundant in the East China Sea, ${ }^{7}$ there is no definite assessment of it. Oil reserve estimates for the East China Sea vary within the same general range. Official Chinese unproven oil reserve estimates tend to vary and tend to be high, at 70 to 160 billion barrels of oil (Bbbl) for the entire East China Sea. Foreign estimates fall closer to the middle of that range at $100 \mathrm{Bbbl}$. As for gas, Chinese estimates of potential East China Sea gas reserves on the entire shelf range from 175 trillion to 210 trillion cubic feet in volume. ${ }^{8}$ Such an abundant oil reserve creates the possibility of fighting for energy among the parties concerned in the East China Sea region. This is especially clear when the oil consumption for those parties is taken into consideration. ${ }^{9}$

As for the fishery resources in the East China Sea, they are rapidly being exploited by the people of the region, who are heavily concentrated along the coastline. Overfishing or a declining average annual fish catch now threatens the extensive fishing industry. Many fishermen are forced to apply more efficient but aggressive fishing techniques, and to venture further out to new fishing grounds. Even worse, fishing in the overlapping areas becomes ordinary practices and creates more disputes among the States related.

It is common that tensions will be mounting in a region where resources are getting fewer and fewer, and demand is on the rise. Owing to its economic development and the change of diet habits, China is consuming more and more fish. In the same time, it is also a fact that China plays an important role of fishing States in the world. ${ }^{10}$ Under the situation that global fish stocks are down, especially the catches in the East China Sea region, this would make perfect sense that Chinese fishing vessels are going farther and farther and into disputed waters. In terms of the Diao Yu Tai Islands, the fishing ground there attracts fishermen from along the northeastern coastline of Taiwan and the eastern part of Fujian. Chinese fishermen have been working there for generations, but in recent years, Japan's coastguard has been increasingly active, confronting Taiwanese and Chinese fishing vessels, which makes the situation more complicated. ${ }^{11}$

7 K.O. Emery, Geological Structure and Some Water Characteristics of the East China Sea and the Yellow Sea, ccop Technical Bulletin 41 (1969).

8 Energy Information Administration, supra note 3; also see Selig S. Harrison, Seabed Petroleum in Northeast Asia: Conflict or Cooperation? in Selig S. HaRrison, (ED.), SEABEd Petroleum in Northeast Asia: Conflict or Cooperation? 5 (2005).

9 Energy Information Administration (EIA), Country Analysis Briefs: South China Sea, available at http://www.eia.gov/EMEU/cabs/East_China_Sea/pdf.

10 For example, China, Peru and Indonesia were the top producing countries in 2008. China remained by far the global leader with production of about 15 million tonnes. FAO, supra note 4 , at 5 .

11 AFP, Fading Fish Stocks Driving Asian Sea Rivalries, 15 November 2010. 
It is not the purpose of this article to define the term "global governance" as there are a variety of definitions on this subject. Instead, the author would like to use the concept of cooperation to describe the on-going processes of managing and conserving fishery resources. Such processes include international instruments, international organizations, and behavior of States.

\section{$\mathbf{1}$}

\section{International Instruments}

Basically, the 1982 United Nations Convention on the Law of the Sea ${ }^{12}$ (hereinafter cited as "UNCLOS") and the 1995 Agreement for the Implementation of the Provisions of the United Nations Convention on the Law of the Sea of 10 December 1982 Relating to the Conservation and Management of Straddling Fish Stocks and Highly Migratory Fish Stocks ${ }^{13}$ (hereinafter cited as "UNFSA") provide certain possibilities on the regulation of cooperation among States in dealing with the issues of high seas fisheries.

One of the basic issues to be considered is the nature of the duty to cooperate. It is noteworthy that the duty to cooperate among States which applies whether they are amicable or antagonistic against each other, could be traced back to certain documents made more than three decades ago. In a declaration adopted by the General Assembly of the United Nations in $1970,{ }^{14}$ states that "States have the duty to cooperate with one another, irrespective of the differences in their political, economic and social systems, in the various spheres of international relations..."

This duty can be characterized into one of two forms: a duty to enter into negotiations; and a duty to negotiate and to reach an agreement. Obviously, both duties of cooperation will require negotiations to be entered into in good faith. Moreover, the parties concerned shall be obliged to work together in good faith to attempt to reach an agreement, and to carry that agreement through to a successful conclusion. ${ }^{15}$ Under such considerations, certain provisions regulated in the UNCLOS and the UNFSA embrace the spirit of cooperation.

12 The UnCLOS entered into force on 16 November 1994 and there are 160 States which have ratified this Convention. See, Status of the Convention, available at http://www.un.org/ Depts/los/reference_files/status2010.pdf.

13 The UNFSA entered into force on 11 December 2001 and there are 67 States which have ratified the Agreement. Ibid.

141970 Declaration on Principles of International Law concerning Friendly Relations and Cooperation among States in accordance with the Charter of the United Nations, GA Res. 2625(XXv), 24 October 1970.

15 L. Guruswamy, The Promise of the United Natins Convention on the Law of the Sea:Justice and Environmental Disputes, 25 Ecology LaW QUarterly 189 (1998), cited in StUarT M. Kaye, International Fisheries Management 111 (2001). 
According to Article 118 of UNCLOS, States fishing on the same living marine resources or in the same area of the high seas shall cooperate in the conservation of these resources. With respect to straddling fish stocks and highly migratory species on the high seas, such obligation is supplemented with the special obligations of the relevant coastal States and States fishing for these stocks in adjacent areas of the high seas to cooperate for the conservation of these stocks. ${ }^{16}$ Taking into consideration the practices in recent years from States and international organizations, these obligations have become part of international customary law. ${ }^{17}$

Part 3 of the UNFSA includes several provisions for mechanisms for cooperation on the conservation of straddling fish stocks and highly migratory species. Although the introductory paragraph of Article 8 seems to leave States a choice whether to cooperate directly or through regional or subregional fisheries management organizations or arrangements, the ensuing paragraphs place radical limitations on this freedom. Where there exists a fisheries management organization or an arrangement competent to regulate the fishery for a specific straddling fish stock or highly migratory fish stocks, those States fishing for the stocks on the high seas and the relevant coastal States shall become members of the organization or participants of the arrangement. ${ }^{18}$

States fishing for the stock on the high seas may choose not to join or participate but are then obligated to apply the management measures adopted by the organization or arrangement, in order to be entitled to fish on the stock. ${ }^{19}$ If the straddling fish stock or highly migratory fish stocks is not subjected to the regulatory competence of any organization or arrangement, States fishing for the stock on the high seas and the relevant coastal States are obligated to establish either an organization or other appropriate arrangements. ${ }^{20}$

2

\section{International Organizations: Regional Fisheries}

Management Organizations

In the absence of an effective centralized authority in dealing with the matters of fishing issues, then probably the regional fisheries organization is an alternative to secure sustainable conservation and management of transboundary

\footnotetext{
16 UNCLOS, Articles 63(2) and 64(1).

17 Also see Tore Henriksen, Geir Honneland, and are Sydnes, Law and Politics in Ocean Governance: The UN Fish Stocks Agreement and Regional Fisheries Management Regimes 15 (2006).

18 UNFSA, Article 8(3).

19 UNFSA, Article 8(4).

20 UNFSA, Article 8(5).
} 
marine resources. Such regional fisheries cooperation involves efforts by States to overcome collective action problems related to the use of shared and common fisheries. This cooperation arises when two or more States concerned identify a shared problem or goal which requires a common and cooperative solution. Such cooperation is often formalized through bilateral or multilateral agreements establishing principles, rules, procedures and institutional organizations for the implementation of cooperation between the parties. In many cases, these agreements are institutionalized by the formation of Regional Fishery Management Organizations (hereinafter cited as RFMOs). ${ }^{21}$

Most of the RFMOs operative in developing regions during the 1950s and 196os were established at the initiative of the Food and Agriculture Organization of the United Nations (FAO). They were constituted with broad mandates to promote research, development and management, but without regulatory powers. Moreover, these organizations were established as development mechanisms, their operations dependent on funding from FAO and other donors. Thus, for the functions to be fulfilled, they relied heavily on the political will of members of the RFMOs to enforce regulations. ${ }^{22}$

Some scholars mention that the cooperative governance problem in marine resources management is to provide adequate means for meeting three major tasks: generation of adequate and reasonably consensual scientific knowledge to permit informed judgments about whether and how exploitation of resources shall be conducted; adoption of legitimate and appropriate regulatory measures to govern economic activities while taking heed of existing knowledge; and a system to promote compliance with such measures among those engaged in resource use in the area. ${ }^{23}$ Therefore, the latter two problems, i.e., regulatory measures and compliance of the members, rely heavily upon members' positive practices.

Even so, some of the RFMOs had taken steps to improve their performance in managing and conserving marine living resources. The author shall take the Inter-American Tropical Tuna Commission (IATTC) for instance, to examine

21 Are K. Sydnes, Regional Fishery Organizations: How and Why Organizational Diversity Matters, 32 Ocean Development and International LaW 350-351 (2001). Also see, Are K. Sydnes, Regional Fisheries Organizations and International Fisheries Governance, in Syma Ebbin, Alf Hoel, and are K. Sydnes (eds.), A Sea Change: The ExClusive Economic Zone and Governance Institutions for Living Marine RESOURCES 117-133 (2005).

22 Are K. Sydnes, Regional Fishery Organizations in Developing Regions: Adapting to Changes in International Fisheries Law, 26 MARINe Policy 374 (2002).

23 Olav Schram Stokke, Governance of High Seas Fisheries: The Role of Regime Linkages, in Davor Vidas and Willy Ostreng (eds.), Order for the Oceans at the Turn of the Century 159, 162-170 (1999). 
its progress. IATTC was established in $195^{\circ}$ in accordance with the entry into force of the 1949 Convention for the Establishment of an Inter-American Tropical Tuna Commission. ${ }^{24}$ After almost fifty years, it was decided that the IATTC (Commission) and the 1949 IATTC (Convention) should be strengthened and modernized to take into account recently adopted international instruments, such as UNClos, the 1992 Agenda 21 and Rio Declaration, the 1993 FAO Agreement to Promote Compliance with International Conservation and Management Measures by Fishing Vessels on the High Seas, the 1995 FAO Code of Conduct for Responsible Fisheries, and the 1995 UNFSA. ${ }^{25}$ An ad hoc Working Group was formed to review the 1949 Convention. ${ }^{26}$

The revising work was done in June 2003 with the adoption of an amended convention. ${ }^{27}$ According to Article 10 of the Antigua Convention, a Committee for the Review of Implementation of Measures Adopted by the Commission is established to: (a) review and monitor compliance with conservation and management measures adopted by the Commission, as well as other cooperative measures; (b) analyze information and any other information necessary to carry out its functions; (c) provide the Commission with information, technical advice and recommendations relating to the implementation of, and compliance with, conservation and management measures; (d) recommend to the Commission means of promoting compatibility; (e) recommend to the Commission means to promote the effective implementation of the Antigua Convention; (f) in consultation with the Scientific Advisory Committee, recommend to the Commission the priorities and objectives of the program for data collection and monitoring of this Convention and assess and evaluate the results of that program; (g) perform other functions. ${ }^{28}$

Furthermore, Article 18 provides that Parties shall take the measures necessary to ensure the implementation of and compliance with the Antigua Convention and any conservation and management measures adopted pursuant thereto, including the adoption of the necessary laws and regulations. Also, Parties shall provide to the Commission all the information that may be

24 For 1949 Convention, available at http://www.iattc.org/PDFFiles/IATTC_convention_1949 .pdf.

25 IATTC, Resolution on the Establishment of a Working Group to Review the IATTC Convention, June 1998.

26 Ibid.

27 Convention for the Strengthening of the Inter-American Tropical Tuna Commission Established by the 1949 Convention between the United States of America and the Republic of Costa Rica (also known as "Antigua Convention"). For full text, available at http://www .iattc.org/PDFFiles2/Antigua_Convention_Jun_2003.pdf.

28 Annex 3, Committee for the Review of Implementation of Measures Adopted by the Commission, Antigua Convention. 
required for the fulfillment of the objective of the Antigua Convention, including statistical and biological information and information concerning its fishing activities in the Convention Area, and shall provide to the Commission information regarding actions taken to implement the measures adopted in accordance with the Antigua Convention.

Except for the actions made by the IATTC, other RFM os take similar actions either by adopting resolutions or taking related measures so that the conservation and management measures could be achieved. ${ }^{29}$

From the aforementioned discussion, it might be safe to conclude that the RFMOs and arrangements are given exclusive competence to regulate the high seas fisheries of straddling fish stocks and highly migratory fish stocks. ${ }^{30}$

\section{Regional Cooperation in the Semi-Enclosed Sea}

In terms of geographical location, the East China Sea could be categorized as a "semi-enclosed sea", which is defined in Article 122 of UNCLOS as follows:

"[E]nclosed or semi-enclosed sea" means a gulf, basin or sea surrounded by two or more States and connected to another sea or the ocean by a narrow outlet or consisting entirely or primarily of the territorial seas and exclusive economic zones of two or more coastal States.

Because the East China Sea is semi-enclosed, any change in the ecosystem of the semi-enclosed sea will have significant impact on the whole area. It is generally recognized that the living resources in the East China Sea area migrate from one EEZ to another, particularly highly migratory species, such as tuna and other shared stocks. Each country may already have its own assessment of its living resources in its EEZ, assuming that the definition and delineation of

29 For example, on 27 December 2000, the International Commission for the Conservation of Atlantic Tunas (ICCAT) adopted a resolution under the title of Supplemental Resolution by ICCAT to Enhance the Effectiveness of the ICCAT Measures to Eliminate Illegal, Unregulated and Unreported Fishing Activities by Large-Scale Tuna Longline Vessels in the Convention Area and Other Areas. Under this resolution, the ICCAT Commission urged Japan and Taiwan to take the necessary measures to complete the scrapping of IUU vessels built in Japan and Taiwan.

30 Tore Henriksen, Geir Honneland, and are Sydnes, law and Politics in Ocean Governance: The Un Fish Stocks Agreement and Regional Fisheries Management Regimes 16 (2006); Robin Churchill and A.V. Lowe, The LaW OF THE SEA 309 (1999); F.O. Vicuna, The International Law to High Seas Fisheries: From Unrestricted Freedom of Fishing to Sustainable Use, in O.S. STOKKe (ED.), Governing High SeAs Fisheries 40-42 (2001). 
each EEZ is clear. The problem is that many of those EEz boundaries are not well defined or mutually agreed upon by the relevant parties. Likewise, there are various conflicting claims to islands that complicate and defer the determination of the EEZ boundaries. For this reason, many experts and scholars are convinced of the need to cooperate on the assessment of the living resources in the East China Sea area without regard to jurisdictional boundaries. The basis for this endeavor would be Article 123 of UNCLOS regarding enclosed and semi-enclosed seas. UNCLOS has foreseen this problem, since Article 123 provides:

States bordering an enclosed or semi-enclosed sea should cooperate with each other in the exercise of their rights and in the performance of their duties under this Convention. To this end they shall endeavour, directly or through an appropriate regional organisation:

(a) to coordinate the management, conservation, exploration and exploitation of the living resources of the sea;

(b) to coordinate the implementation of their rights and duties with respect to the protection and preservation of the marine environment;

(c) to coordinate their scientific research policies and undertake where appropriate joint programmes of scientific research in the area;

(d) to invite, as appropriate, other interested States or international organisations to cooperate with them in furtherance of the provisions of this article.

Therefore, all parties concerned should be aware that fish are migratory and fishery resources are exhaustible, so that rational use of the East China Sea and the preservation of its marine environment are important to all parties. Thus, cooperation among littoral States in the region is essential. In order to avoid overfishing or depletion of resources, conservation measures have to be taken. Such measures are not possible without regional cooperation and require close coordination among the parties concerned, especially in a semi-enclosed sea.

Indeed, a semi-enclosed sea concept could conceivably provide the catalyst to promote cooperation and coordination of the management of resources in the disputed region. ${ }^{31}$ Under such circumstances, for all the littoral States to make boundary delimitation issue the first priority seems unwise. Rather, concentrating upon their common interests will be an essential motivation to resolve conflicts rationally.

31 Lee G. Cordner, The Spratly Islands Dispute and the Law of the Sea, 25 OCEAN DevelopMENT AND INTERNATIONAL LAW 71 (1994). 
Fishery cooperation could be the most feasible course of action for the littoral States since through cooperation, fishery resources could be properly conserved and managed such that economic waste and over-exploitation may be avoided. Cooperation in the utilization of fishery resources is a feasible and practical way to start a regional cooperation regime. It sidesteps the issue of sovereignty and focuses upon a common interest, namely the utilization of living resources. It also defers long-term negotiations with respect to delimitation of the continental shelf relating to the hydrocarbon resource issue. Thus, as cooperative relationships are forged with regard to fishery resources, mutual confidence will build among the various parties that may eventually contribute to successful cooperation with respect to hydrocarbon resources. Fishery resources management is crucial in preventing over-exploitation or overfishing and may be a touchstone of the littoral States' sincerity.

Without affecting jurisdictional boundaries as laid down in the UNCLOS, it is certainly possible to have regional joint fishery management in the East China Sea as the starting point for further cooperation. If all States in this region treat cooperation as a key step toward achieving mutual benefit, then the future for such a regional cooperation mechanism is assured.

\section{Pursuing Sustainable Fisheries}

Fishing or fishery is a vital aspect of the world's diet, economy, and biodiversity. However, overwhelming evidence shows that these crucial uses of the marine world are in danger. Under such circumstances, the depletion of fishery resources is not a crisis for food, but also a crisis for environment.

The history of high-seas fisheries management over the last $15^{\circ}$ years can be classified into three phases. The first phase, up until the early 1970s, saw a rapid increase in both the number of fishing vessels operating in the individual oceans and advances in technology which allowed greater catches. The phase was characterized by generally narrow coastal State maritime zones and large areas of high seas. Also, a considerable proportion of fisheries in the high seas fell under the jurisdiction of international or regional fishery commissions by the mid-1970s. The second phase, the period from the mid-1970s up until the early 1990s, reflected the developments and negotiations of the Third United Nations Conference on the Law of the Sea. Owing to the practices on claiming exclusive economic zone from countries, coastal States extended their jurisdiction out to 200 nautical miles so that many areas (and fisheries) that were previously classified as high seas came under national jurisdiction. The area defined as high seas was thus considerably reduced and consequently so was the area under the jurisdiction of regional and international 
fisheries commissions. Since the mid-199os, high-seas fisheries management has entered its third phase. This phase reflects the international community's concerns about overfishing in the high seas. Even greater emphasis has been placed on the international duties and responsibilities of all nations in the conservation of ocean resources, as well as the importance of cooperation between States both adjacent to the fisheries and those exploiting them. ${ }^{32}$

For the purposes of conserving and managing marine living resources, traditional thought on utilization should be transformed to sustainability. In order to reach this object, "sustainable development" is one of the main policy bases, under which sustainable development is the development that "meets the needs of the present generation without compromising the ability of future generations to meet their own needs". ${ }^{33}$ Governments should take this position in making the fishery policy, but not concentrate on increasing fishing capacity or the amount of fishing, especially when the FAO reiterates the serious situation in the 1999 International Plan of Action for the Management of Fishing Capacity. ${ }^{34}$

Following on the concept of sustainable development of fisheries, another consideration that should be taken when making policy on fisheries is the "precautionary approach". The concept of the precautionary approach developed in the mid-1980s and in regional legal instruments for the protection of the terrestrial, and subsequently marine, environment, and finally enshrined in Principle 15 of the 1992 Rio Declaration, ${ }^{35}$ which states:

In order to protect the environment, the precautionary approach shall be widely applied by States according to their capabilities. Where there are threats of serious or irreversible damage, lack of full scientific certainty shall not be used as a reason for postponing cost-effective measures to prevent environmental degradation.

Based on the precautionary approach, the UNFSA not only includes this approach as a kind of duty to cooperate, ${ }^{36}$ but also demands the application of the precautionary approach. This can be seen from Article 6 of the UNFSA:

32 Sevaly Sen, The Evolution of High-Seas Fisheries Management in the North-East Atlantic, 35 Ocean \& Coastal Management 85-86 (1997).

33 World Commission on Environment and Development, Our Common FUTURE 43 (1987).

34 Rosemary Rayfuse, The Challenge of Sustainable High Seas Fisheries, in Nico SCHRIJVER and Friedl Weiss (eds.), International law and Sustainable Development: Principles and Practice 469-477 (2004). MENT, Rio de Janeiro, 3-14 June 1992, A/CONF.151/26 (Vol. I), 12 August 1996. UNFSA, Article 5(c). 
1. States shall apply the precautionary approach widely to conservation, management and exploitation of straddling fish stocks and highly migratory fish stocks in order to protect the living marine resources and preserve the marine environment.

2. States shall be more cautious when information is uncertain, unreliable or inadequate. The absence of adequate scientific information shall not be used as a reason for postponing or failing to take conservation and management measures.

3. In implementing the precautionary approach, States shall:

(a) improve decision-making for fishery resource conservation and management by obtaining and sharing the best scientific information available and implementing improved techniques for dealing with risk and uncertainty; ...

Such consideration has to be taken into account when a natural phenomenon has a significant adverse impact on the status of straddling fishing stocks or highly migratory fish stocks, States shall adopt conservation and management measures on an emergency basis to ensure that fishing activity does not exacerbate such adverse impact. States shall also adopt such measures on an emergency basis where fishing activity presents a serious threat to the sustainability of such stocks. ${ }^{37}$

Policy assessment is one of the most important parts in a policy-making circle. During the period of focusing on economic development and trading, exploring the marine living resources and increasing the production might be the right choice. However, under a globalized world, it is hard to distinguish the complicated web of influence between trade and environment. So is the fishery. Nonetheless, since we are in the phase of conserving and managing fishery resources, and international instruments and RFMOs have already embedded the concepts of sustainability and precaution into the fishery activities, then it might be the right time and right choice to adjust fisheries policy bases to a more environmental deliberation. Moreover, States bordering the semienclosed sea should have responsibilities to embed the consideration of regional cooperation into its national ocean policy.

\section{$1 \quad$ A Positive Development: Taiwan-Japan Fisheries Agreement}

After Japan announced its nationalization of Diaoyutai/Senkaku Islands on 11 September 2012, the tension in the East China Sea has been on the verge of breaking out into a serious conflict. In responding to Japan's announcement, China and Taiwan issued tough statements against Japan's action. 
China's foreign minister Yang said that the "moves taken by Japan are totally illegal and invalid", he said. "They can in no way change the historical fact that Japan stole Diaoyu and its affiliated islands from China and the fact that China has territorial sovereignty over them". He continually said that the Japanese government had "grossly violated China's sovereignty".38

Also, Taiwan's Foreign Ministry lodged a strong protest against Japan, calling the island purchase an "extremely unfriendly move" that "not only harms the longtime cooperation between Taiwan and Japan but will also aggravate regional tensions in East Asia".39

Seven months later, the conclusion of the Taiwan-Japan Fisheries Agreement on 10 April 2013 (hereinafter cited as "the Agreement") was a development considered as a way to defuse the tension ${ }^{40}$ because Taiwan and Japan were trying to solve the dispute through a more pragmatic way. Furthermore, a more detailed examination of the provisions in the Agreement show that it conforms to the spirit of 'provisional arrangements' provided for in UNCLOS.

The background for finalizing the Agreement is mixed with international politics as well as international law significance. In terms of international politics, the East China Sea has always been an important strategic sea lane and Diaoyutai/Senkaku Islands play a key role in this context. Japan wants to protect its strategic interests in the East China Sea and tries to prevent Taiwan from cooperating with China while the conflict between Japan and China remained. In addition, the influence from the United States should not be ignored. Both Japan and Taiwan are important to the United States in guarding its rebalancing strategy in East Asia. ${ }^{41}$ Under such circumstances, the joint fisheries cooperation between Taiwan and Japan would be a positive way to ease off the tension as well as maintain US strategic interests.

As far as resources management is concerned, it is understandable that any change in the ecosystem of the semi-enclosed East China Sea would have significant impact on the whole area. In addition, it also demonstrated the need

38 Japan and China Trade Barbs over Islands at UN, ввС NEWs, 28 September 2012, available at http://www.bbc.com/news/world-asia-19754353.

39 China Sends Patrol Ships to Islands Held by Japan, The Seattle Times, 12 September 2012, available at http://www.seattletimes.com/nation-world/china-sends-patrol-ships -to-islands-held-by-japan/.

40 The Library of Congress, Japan; Taiwan: Landmark Fishing Agreement, available at http:// www.loc.gov/law/foreign-news/article/japan-taiwan-landmark-fishing-agreement; and http://www.mofa.gov.tw/Upload/WebArchive/979/The\%2oTaiwan-Japan\%2oFisheries\%20Agreement\%2o(illustrated\%2opamphlet).PDF.

41 For "rebalancing strategy", see Robert G. Sutter, Michael E. Brown, and Timothy J. A. Adamson, Balancing Acts: The U.S. Rebalance and Asia-Pacific Stability, August 2013, available at https://www2.gwu.edu/ sigur/assets/docs/BalancingActs_Compiledı.pdf. 
to cooperate on the conservation and management of the living resources in the East China Sea region without regard to sovereignty claims or maritime boundaries. The basis for this endeavor would be the practices of provisional arrangements in Articles 74(3) and 83(3), as well as the rights and duties for States boarding semi-enclosed seas to cooperate on coordinating the management, conservation, exploration and exploitation of the living resources in Article 123 of UNCLOS.

Four parts included in the Taiwan-Japan Fisheries Agreement are in accordance with those provisions mentioned above: ${ }^{42}$

1. Object of the Agreement: The purpose is to promote conservation and utilization of marine living resources in the overlapping exclusive economic zone between Taiwan and Japan. In other words, the Agreement touches upon the sovereign rights issues as well as promoting the management of living resources, such as tuna, billfish, bonito, and mackerel. It does not refer to the sovereignty issue over Diaoyutai/Senkaku Islands.

2. Fisheries Cooperation Area: The Agreement will be applicable to a Designated Zone which is south of 27 degrees north latitude and north of Japan's Yaeyama Islands and Miyako Islands, covering an area of 74,000 square kilometers. (See Map 1) Two sub-areas are allocated as follows:

2.1 Waters where the other party's laws are not applicable: After entry into force of the Agreement, one party's fisheries laws and regulations will not be applicable to the other party's fishing activities. In other words, fishing activities are governed by each party's national laws and regulations. Any intervention from the other party shall not be allowed.

2.2 A special cooperation zone: In an area within the Designated Zone where disputes frequently arise between fishing vessels from both parties, a special cooperation zone has been created. Both parties cooperate under the principles of equality and reciprocity with regards to fishing operations in this area. Details concerning this arrangement will be discussed by a Taiwan-Japan Fishery Committee formed from the Agreement.

3. Management Body: The Taiwan-Japan Fishery Committee was created and held its first meeting in Taipei on 7 May $2013,{ }^{43}$ in accordance with

42 Dustin Kuan-Hsiung Wang, Taiwan-Japan Fisheries Agreement: Light at the End of a Dark Tunnel, 1 (1) Asia-Pacific Journal of Ocean LaW And Policy 127-130 (2016).

43 Up to this date, five meetings have been carried out. The second meeting was in Tokyo on 26 December 2013; the third meeting was in Taipei on 23 January 2014; the fourth one was back to Tokyo on 7 March 2015; and the fifth one was on 2 March 2016 in Taipei. 
the provisions of the Agreement. This committee is an institutionalized joint management mechanism created with aiming to maintain order in fishing operations and preserve the living resources in the Designated Zone.

4. Without-Prejudice Clause: Both parties consented to the inclusion of a without-prejudice clause to ensure that the provisions of the Agreement do not undermine their position on and interpretation of international law regarding its sovereignty and maritime claims, affirming their consistent position on the issue of sovereignty claims.

In terms of legal significance, the Taiwan-Japan Fisheries Agreement is a positive contribution in State practice fulfilling the spirit of UNCLOS, especially the concept of provisional arrangements.

According to the Agreement, the maritime area of 12 nautical miles surrounding the Diaoyutai/Senkaku Islands is excluded from the cooperation mechanism in the Designated Zone. This is an arrangement of "shelving sovereignty disputes" and focusing on living resources joint cooperation matters, which conforms to the spirit of joint development. However, the sovereignty issue over those islands will be subject to future negotiations rather than changing or even giving up the position on sovereignty claims. The Agreement itself is a great progress not only in stabilizing the tension in the East China Sea, but also in realizing the term 'provisional arrangements' provided in UNCLOS in Articles 74(3) on EEZ delimitation and 83(3) on continental shelf delimitation.

Moreover, under the UNCLOS framework, a semi-enclosed sea could conceivably provide the catalyst to promote cooperation and coordination of the management of resources in the East China Sea. Concentrating upon common interests will provide the essential motivation to resolve the conflicts rationally. Hence, fishery cooperation would be a feasible course of action for the parties concerned since through cooperation, fishery resources could be properly conserved and managed so that the resources could be utilized in a sustainable way. The Agreement is a good start for sustaining peace in the East China Sea. It focuses on the fisheries issue and puts aside territorial sovereignty or maritime delimitation considerations, which is a praise worthy move made by both Taiwan and Japan. It is also a remarkable practice of 'provisional arrangements' stipulated in the UNCLOS.

The discussion were mainly on the issues of reducing fishery conflicts between fishermen from both sides through setting fishing regulations as well as communication measures. 


\section{Conclusion}

Under the circumstances that EEZ has become customary international law, all States, especially those in the region of the East China Sea, had claimed different maritime zones to extend their jurisdiction over living and non-living resources of these zones. This then is the central element with regard to the disputes in the region. There are three motivating factors behind the conflicts: the first one relates to strategic or political concerns, whilst the other two relate to resource utilization or economic considerations. These factors are interrelated, which further complicates the disputes. However, such situation should not prevail over the consideration of resolving the issue from a pragmatic viewpoint. The idea of cooperation has gradually come to play an important role in a semi-enclosed region like the East China Sea. For this reason, building up an East China Sea RFmo could be the starting step and the newly concluded Taiwan-Japan Fisheries Agreement might be a pilot project. Not only for the fact that fish migrates without regard to State borders and needs careful conservation and management, but also for possibility that the successful experience might spill-over into other controversial issues. Unless a State is ready to go to war over its terra irredenta, the best solution is the will to arrive at a non-boundary-based settlement that guarantees peace and progress for all parties concerned. 